\title{
ROTEIRO GEOLÓGICO DA BACIA DO ALMADA, BAHIA
}

\author{
ANTÓNIO S.T. NETTO* \& CHRISTOVAM P.SANCHES*
}

\begin{abstract}
FIELD GUIDE TO ALMADA BASIN, BAHIA, BRASIL. The Rio Almada Basin lies along the Bahia coast, between parallels $14^{\circ} \mathrm{S}$ (Taipus high) and $15^{\circ} \mathrm{S}$ (Oliver ${ }^{\wedge}$ a high), and extend offshore until the oceanic crust. Age of sediments range from Jurassic to Recent. All the formations are exposed in a $200 \mathrm{~km}^{2}$ area north of Ilheus, Bahia, in which three structural compartments are delineated. The field guide covers the structural aspects, visit both basements, Archean metamorphics and Proterozoic igneous rocks, but mostly describes the main outcrops of the sedimentary section. There are good outcrops of Jurassic alluvial fans reworked by aeolian process on top, lower Cretaceous rift-fill sediments, upper Cretaceous marine channelized turbidites from the drift phase, Cenozoic barrier-bar and shoreface deposits and Recent beach-rocks. A scheme is put together for a three days self-guided field trip.
\end{abstract}

Keywords: Stratigraphy, Bahia, etroleo, roteiro geológico, guia, Bacia do Almada

RESUMO A bacia sedintentar do Rio Almada ocupa a faixa litorânea compreendida entre os paralelos de $14^{\circ}$ $\mathrm{S}$ (Alto de Taipus) e $15^{\circ} \mathrm{S}$ (Alto de Olivença) e estende-se mar adentro até a crosta oceânica. A idade dos sedimentos contidos varia do Jurássico ao Recente. Numa área de $200 \mathrm{~km}^{2}$ a norte de Ilhéus, Bahia, toda a seção está exposta e distribuída em três compartimentos estruturais. Este roteiro aborda o arcabouço estrutural da parte emersa, visita o embasamento metamórfico arqueano. o embasamento ígneo do Proterozóico Médio e principalmente descreve os afloramentos mais ilustrativos da seção sedimentar. Estão particularmente bem expostos os leques aluviais com retrabalharnento eólico do Jurássico, os sedimentos depositados no ríft-valley do Cretáceo Superior, as restingas Cenozóicas e os beach-rocks recentes. A visita cobrindo todos os aspectos comentados pode ser realizada sem guia, e está esquematizada no roteiro para um período de três dias.

Palavras-chaves: Stratigraphy, Bahia, oil and gás, field guide, Almada Basin.

INTRODUÇÃo A bacia sedimentar do Rio Almada, na parte emersa, aflora entre os paralelos de $14^{\circ} 30^{\prime}$ e $15^{\circ} 00^{\prime} \mathrm{S}$, e os meridianos de $39^{\circ} 00^{\prime}$ e $39^{\circ} 14^{\prime} \mathrm{W}$, na forma de um rornboedro de $200 \mathrm{~km}^{2}$, definido por falhas normais de direção nordeste-sudoeste (Fig. 1).

A bacia foi rnapeada na escala 1:25.000, em 1962, pela TG-10 da PETROBRÁS, chefiada por Kilson W. Carvalho, que fez publicar seus resultados em 1965 (Carvalho 1965). Junto com o mapeamento de superfície, foi realizado um levantamento gravirnétrico. Em 1966, foi perfurado um poço estratigráfico, que atingiu o embasamento de granulito a 1.435 $\mathrm{m}$, e recuperou $110 \mathrm{~m}$ de testemunhos tomados a espaçamento quase uniforme, de um testemunho a cada $30 \mathrm{~m}$.

Entre dezembro de 1973 e janeiro de 1974, a SUDENE, em convénio com o Governo do Estado da Bahia, fez executar pela SACS/Geofoto duas coberturas com fotografias aéreas da área, cobrindo toda a bacia nas escalas 1:108.000 e 1:60.000. Em junho de 1974, a PETROBRÁS realizou pela ES-39 um programa de sísmica de reflexão em semidetalhe, cobrindo $58 \mathrm{~km}$ lineares com registro digital de 24 canais, numa área de $90 \mathrm{~km}^{2}$. Em 1977, foi perfurado um poço a 1 $\mathrm{km}$ da praia, na plataforma continental, com lâmina cTágua de $11 \mathrm{~m}$. Este poço atingiu o embasamento a $2.212 \mathrm{~m}$ e recuperou gás avaliado como subcornercial (vazão 34.000 $\mathrm{m}^{3} /$ dia AOF), nos intervalos $1.050-1.080 \mathrm{~m}$ e $1.230-1.270 \mathrm{~m}$. Em 1978, foi perfurado um pioneiro em terra que atingiu o embasamento a $1.179 \mathrm{~m}$ e resultou seco. Em 1982, foi realizada uma campanha exploratória na área, com a perfuração de três pioneiros, dois dos quais estavam secos e um que recuperou óleo, no Cretáceo Inferior (Formação Rio de Contas) à profundidade de $1.220 \mathrm{~m}$ e no Jurássico (Formação Sergi) à profundidade de $1.6 \times 10 \mathrm{~m}$. Todos os poços atravessaram a seção sedimentar até o embasamento cristalino.

$\mathrm{O}$ embasamento aflorante na parte norte da bacia e testemunhado pêlos poços exploratórios é constituído por gnaisse de composição granulítica datado como do Arqueano $(2,6 \mathrm{Ga})$. Na parte sul afloram sienitos datados como do Proterozóico Médio (1,7 Ga, Inda \& Barbosa 1978).

ARCABOUÇO ESTRUTURAL A figura 1 ilustra o arcabouço estrutural simplificado da bacia, conforme vislumbrado a partir dos dados de superfície, subsuperfície (poços), sísmica (inclusive na plataforma continental) e gravimetria. As falhas limites que definem o padrão romboédrico (e.g., Falha da Serra Pilheira e Falha do Maron) têm direção geral N-50E e são datadas como Cretáceo Inferior, fase rifte, provavelmente idade Rio da Serra. Elas delimitam a bacia, colocando o embasamento, tanto o metamórfico como o ígneo em bloco alto e a seção sedimentar no bloco baixo. Não há espessamento da seção pré-rifte no bloco baixo. Associado a estes falhamentos sintéticos, ocorre um sistema de falhas antitéticas, de direção dominante N-S e mergulho para oeste (e.g., Falha do Apipique, nomenclatura de Carvalho 1965), que delimitam um compartimento raso, a oeste, onde se situa a Lagoa Encantada. Este compartimento interno, de oeste, estende-se por metade da área emersa da bacia e, para esta área, estima-se que a espessura da seção sedimentar não ultrapasse os $200 \mathrm{~m}$.

Para leste da Falha do Apipique diferencia-se o compartimento central, onde foi realizado um programa sísmico e perfurados dois poços pioneiros. A superfície do embasamento no compartimento central tem forma côncava (Fig. 2), com profundidade média em tomo de $500 \mathrm{~m}$. O limite externo (leste) do compartimento central é balizado pela Falha de Aritaguá, a qual tem componente gravitacional, com bloco baixo para leste, e componente transcorrente, com movimentação sinistral.

A Falha de Aritaguá é rastreada alhures, além dos limites da parte emersa da Bacia de Almada. Seu traço é encurvado, côncavo para leste e seu ponto mais ocidental fica entre os poços FZT-1 e NB-2; no bloco baixo observa-se a presença 

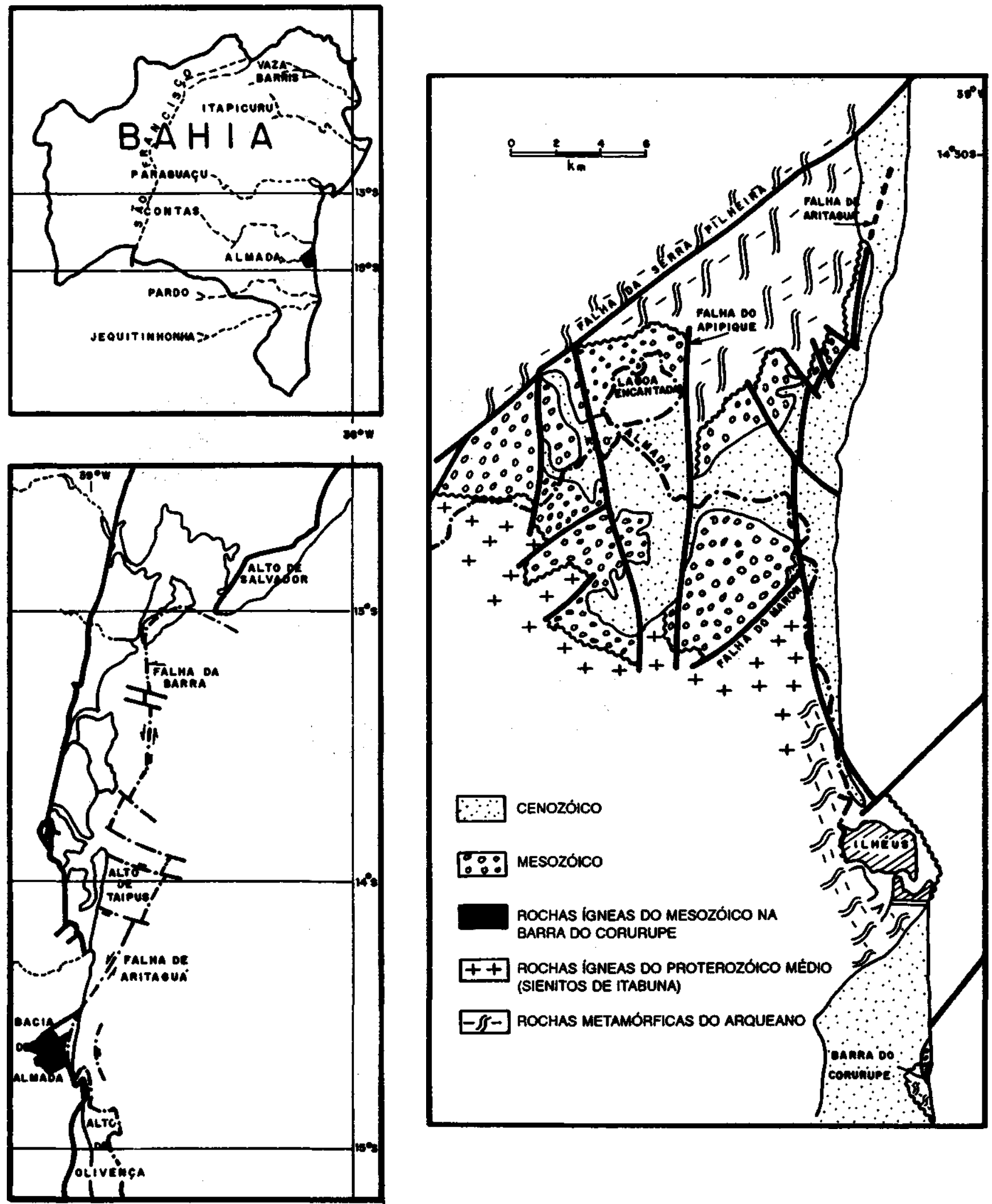

Figura 1 - Situação e arcabouço estrutural da Bacia do Rio Aunada. A pane emersa da bacia esfcnde-se por $200 \mathrm{~km}$ ' em três compartimentos. A oeste da falha do Apipique, fica o compartimento interno, com embasamento a $200 \mathrm{~m}$; a leste da falha de Aritaguá, fica o compartimento externo, co.t embasamento a 1.500 m junto à falha, ajundando rapidamente mar adentro. No talude atual, cuja borda está a uma distância de $20 \mathrm{~km}$ de linha de costa, infere-se que o embasamento da bacia seja a crosta oceânica

Figure I - Almada basin location and structural framework 

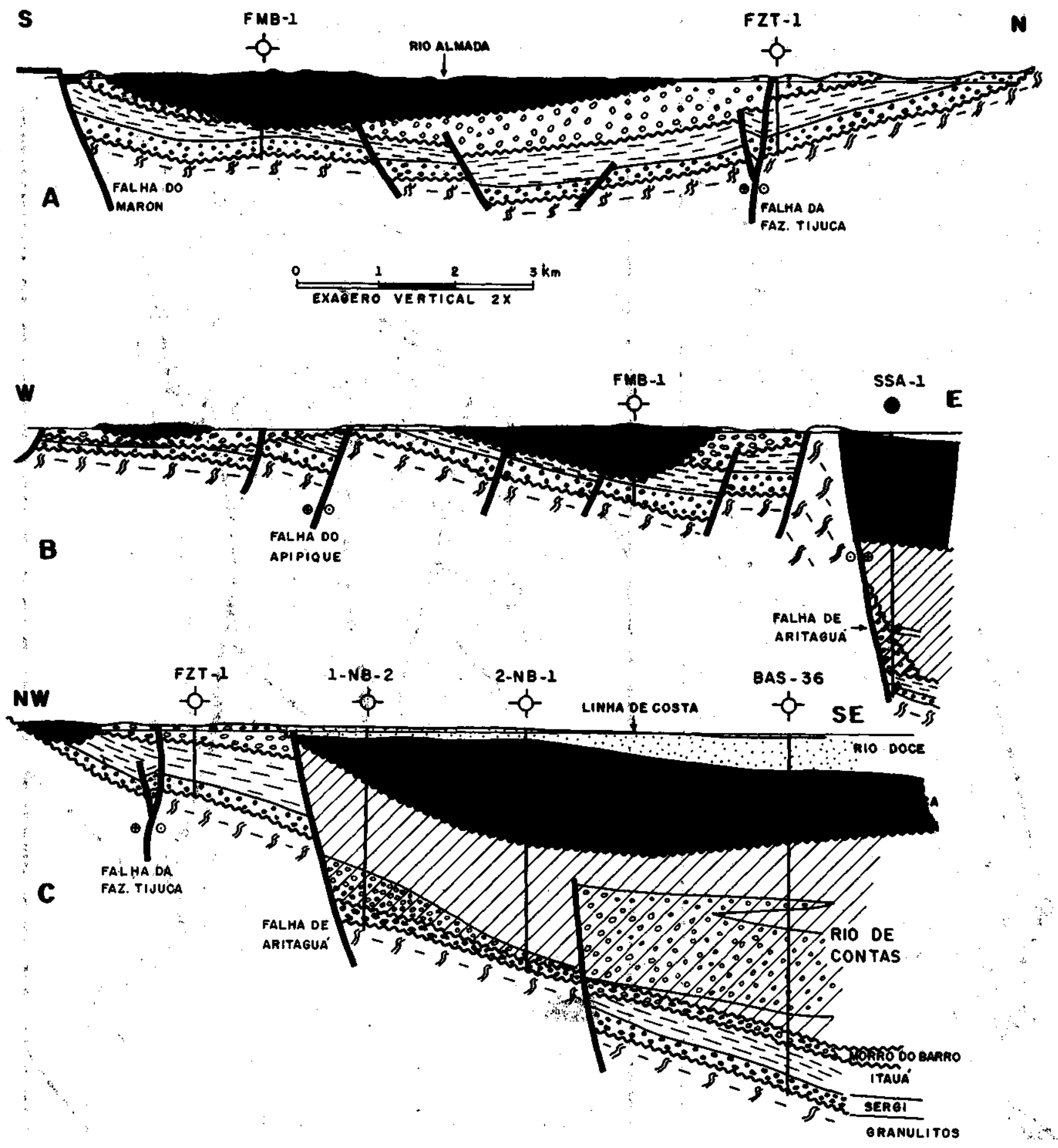

Figura 2- Seções geológicas na Bacia do Almada. Para localização, ver figura 4. A. Compartimento central ao longo da 39-RL105, com fundo da bacia côncavo, embasamento a $500 \mathrm{~m}$. B. Seção transversal ao longo da 39-RL-104: compartimento interno a beste da falha do Apipique; compartimento central no bloco do FMB-1 e compartimento externo a leste da falha deArítaguá. C. Observe a diferença da geometria dos conglomerados na Formação Urucutuca, no talvegue do cânion, e na Formação Rio de

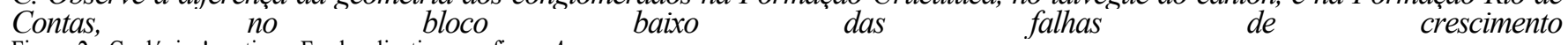
Figure 2- Geológica! sections. For localization, see figure 4

expressiva da Formação Rio de Contas, de idade Jurássica (Cretáceo Inferior, Barremiano), ausente no bloco alto. As rochas sedimentares mais antigas que o Andar Aratu têm o mesmo padrão de espessura em ambos os lados da falha, o que permite datar a Falha de Aritaguá como de idade Buracica. O Rio Almada, ao atingir o traço do plano da Falha de Aritaguá, sofre urna inflexão de quase $90^{\circ}$ para sul, e segue acompanhando sinuosamente o plano da falha, até sua desembocadura, junto ao Porto do Malhado, em Ilhéus. O truncamento da Falha do Maron pela Falha de Aritaguá (Fig. 1) é bem exposto na superficie junto à Vila de Aritaguá e aproveita o contato da intrusão ígnea contra o maciço metamórfico, compondo uma escarpa íngreme alinhada na direção N10. 
Para norte do Rio Almada, o traço da falha de Aritaguá fica escalonado por transcorrências antitéticas, uma das quais é detectada próximo à base do poço FZT-1, na Fazenda Tijuca; neste ponto, o plano da falha antitética é impregnado com óleo escuro, que escapa eventualmente para níveis mais permeáveis na Formação Morro do Barro (Fig. 3a). Mais para norte, o traço da Falha de Aritaguá é deslocado dextralmente (Fig. 4), e seus efeitos podem ser vistos em afloramento da Formação Sergi próximo à vila de Ponta da Tulha; neste afloramento, os seixos de quartzo do conglomerado Sergi apresentam-se cortados (Fig. 3b), e os planos de corte exibem padrão en-echelon (Fig. 3c). Feições de flower-structure também enriquecem a exposição nesta parte norte da bacia (Fig. 3d).

A área emersa a leste da Falha de Aritaguá é o compartimento externo da Bacia do Almada, a qual, à exceção de urna pequena exposição da Formação Rio de Contas (Fig. 4), apresenta superfície inteiramente dominada pêlos sedimentos da Formação Rio Doce, os quais representam o registro do complexo litorâneo nos últimos 50 milhões de anos (do Eoceno até hoje). O registro de sísmica e principalmente as informações de três poços exploratórios perfurados neste compartimento externo, evidenciam o forte controle tectônico na sedimentação do bloco baixo da Falha de Aritaguá (Fig. 2), onde a Formação Rio de Contas apresenta espessura da ordem de $800 \mathrm{~m}$ na estreita faixa emersa da bacia, com tendência a espessamento muito mais expressivo ainda na área da plataforma continental. Datações paleontológicas da seção de calcários, folhelhos, conglomerados e arenitos que compõem esta formação indicam tratar-se de sedimentos não marinhos de idade Buracica. A Formação Rio Doce, na área amostrada pêlos poços, tem espessura da ordem de 40 a $50 \mathrm{~m}$.

Com o perfil de densidade (FDC) dos poços e com o controle de sísmica, a interpretação geológica da configuração estrutural da bacia foi testada num modelamento gravimétrico: foram calculados perfis Bouguer para a configuração interpretada da bacia, os quais foram comparados com o perfil Bouguer medido com o gravímetro. As discrepâncias foram ajustadas atribuindo valores de contrastes de densidade para a parte interna da crosta. Os resultados do modelamento apontam para um afinamento crustal para leste. Na borda oeste da bacia, estima-se uma espessura de crosta da ordem de $25 \mathrm{~km}$, que cai para $20 \mathrm{~km}$ abaixo da linha de costa atual, e para $10 \mathrm{~km}$ de crosta na borda da plataforma continental atual. Com este modelamento, postula-se que a seção sedimentar da Bacia do Almada no talude continental atual, repousa sobre a crosta oceânica.

ESTRATIGRAFIA A seção sedimentar aflorante na Bacia do Almada (Tab. 1) representa a faciologia mais proximal da bacia, incluída a plataforma continental adjacente. A coluna estratigráfica é marcada por cinco grandes discordâncias regionais, sendo comum o retrabalhamento, com reciclagem dos constituintes e mistura de fósseis no registro.

A descrição das rochas sedimentares aflorantes na Bacia do Almada está bem apresentada em Carvalho (1965), junto com a formalização da Formação Urucutuca. Existem, no entanto, diferenças entre a estratigrafia de Carvalho e a aqui apresentada. As diferenças são devidas a que Carvalho $(1965$, p.5) considerou a Bacia do Almada como o extremo sul da Bacia do Recôncavo e, por consequência, procurou estender a nomenclatura estratigráfica do Recôncavo para Almada. Além disso, no inicio da década de 60, quando a Petrobrás procurava essencialmente armadilhas estruturais, as "formações" tinham uma conotação temporal que suplantava a variação litológica. Por fim, o ganho de conhecimento com a exploração na plataforma nas décadas de 70 e 80 permitiu entender â evolução tectônica das fases rifte e drift, e seus efeitos na sedimentação, conhecimento este que necessariamente tem seus reflexos na arrumação da estratigrafia da bacia (Fig. 5).
Tabela 1 - Planirnetria do mapa geológico da Bacia do Rio Almada, da Serra Grande até Ilhéus. Areas em km². Parte emersa da Bacia (de Serra Grande até Ilhéus): 200; compartimento interno: 98; compartimento central: 53; compartimento externo: 49

Table 1 - Planimetry of geológical map of Rio Almada basin, from Serra Grande to Ilhéus. Áreas in $\mathrm{km}^{2}$. Emerged part of the basin (from Serra Grande to ILhéus): 200; internai cornpartment: 98; central compartment: 53; external compartment: 49

\begin{tabular}{l|rc|c}
\hline & \multicolumn{2}{|c|}{$\mathbf{k m}^{2}$} & $\%$ \\
\hline Formação Rio Doce & 100 & 50 \\
\hline Formação Urucutuca & 18 & drift & 9 \\
\hline Formação Rio de Contas & 1 & rifte 12 & 6 \\
Formação Morro de Barro & 11 & & \\
\hline Formação Itauá & 24 & pré-rifte 62 & 31 \\
Formação Sergi & 38 & & 4 \\
\hline Lagoa Encantada & 7 & &
\end{tabular}

A seção sedimentar basal, Formação Sergi e Formação Itâuá, faz parte do sistema subaéreo que dominou a Depressão Afro-Brasileira (Netto 1977, p. 513) no final do Jurássico e início do Cretáceo. O limite sul da Bacia do Almada, o Alto de Olivença, é o limite sul na costa brasileira dos sedimentos pré-rifte, e aqui, na área estudada, a seção pré-rifte só tem preservada a parte superior; a Formação Aliança está ausente. A Formação Sergi tem espessura variável de 50 a $150 \mathrm{~m}$ nos quatro poços que a atravessaram; base erosional contendo arenitos e conglomerados, e topo transicional à Formação Itauá. Por Formação Itauá foram considerados os folhelhos Itaparica, o arenito Água Grande (bem exposto na Fazenda Vencedora, na parte noroeste do compartimento interno) e os folhelhos do Membro Tauá, que Carvalho (1965, p. 17) mapeou como Candeias. Este conjunto é bem desenvolvido, tendo sido atravessado por quatro poços e mostrado espessura que varia de 80 a $260 \mathrm{~m}$. Essa variação é devida à forte discordância no topo, na passagem para a fase distensional do rifte, registrada pela Formação Morro do Barro.

A fase distensional (Rifte I, Fig. 5), de idade Rio da Serra, contém essencialmente a Formação Morro do Barro, com base e topo marcados por discordâncias regionais, e é constituída por conglomerados organizados de seixos achatados, arenitos finos a conglomeráticos, mal selecionados, maciços na maior parte, e folhelhos. O melhor afloramento está no compartimento central, próximo ao poço FZT-1. No FZT-1, a Formação Morro do Barro ocorre da superfície até $70 \mathrm{~m}$, com razão aren/flh $=5$ nos afloramentos próximos ao poço, e razão $\operatorname{aren} / \mathrm{cgl}=2$. Os arenitos são conglomeráticos, maciços, com ondulas no topo das camadas. Numa área mais argilosa constatam-se efeitos de slumping. A seção é interpretada como representativa da zona proxirnal de um sistema de leques subaquosos, proximal-fan, alimentado de NW para SE; "lobos canalizados" na classificação de Bruhn \& Moraes (1989).

A fase transtensional (Rifte II), de idade Buracica-Jiquiá, é representada na área em estudo pela Formação Rio de Contas, com um único e mal preservado afloramento em toda a bacia, na borda oeste do compartimento externo, mas em compensação muito bem testemunhada pelo poço estratigráfico 2-NB-1-Ba. Neste poço, os $423 \mathrm{~m}$ de Rio de Contas têm $297 \mathrm{~m}(70 \%)$ de folhelho cinza e castanho, com restos de peixes e coprólitos, laminado com siltito e arenito mui fino. Uma feição distinta é a presença de calcário, que no poço tem $53 \mathrm{~m}(13 \%)$, mais do que os $39 \mathrm{~m}(9 \%)$ de arenitos que exsudam gás quando sacados do barrilete de testemunhagem (Fuschilo \& Araripe 1966). A base da formação tem uma discordância erosional marcada pela presença de conglomerado (Fig. 5). Como primeira hipótese de trabalho, este inter- 


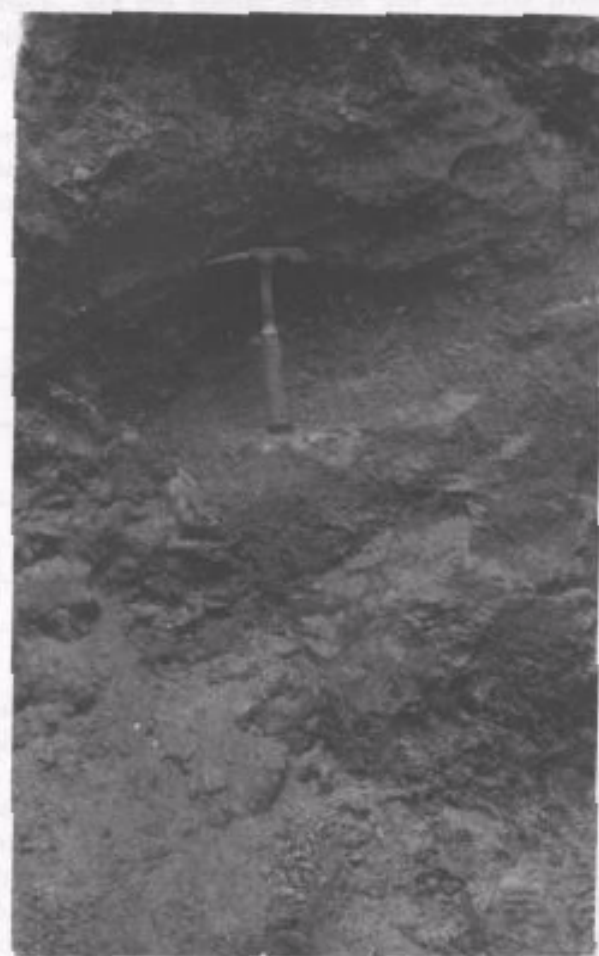

a

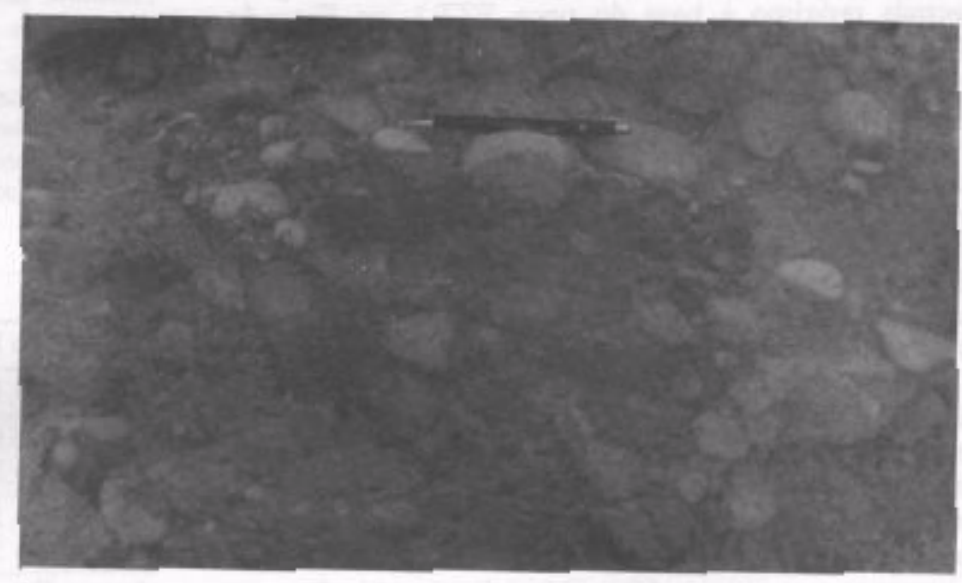

b

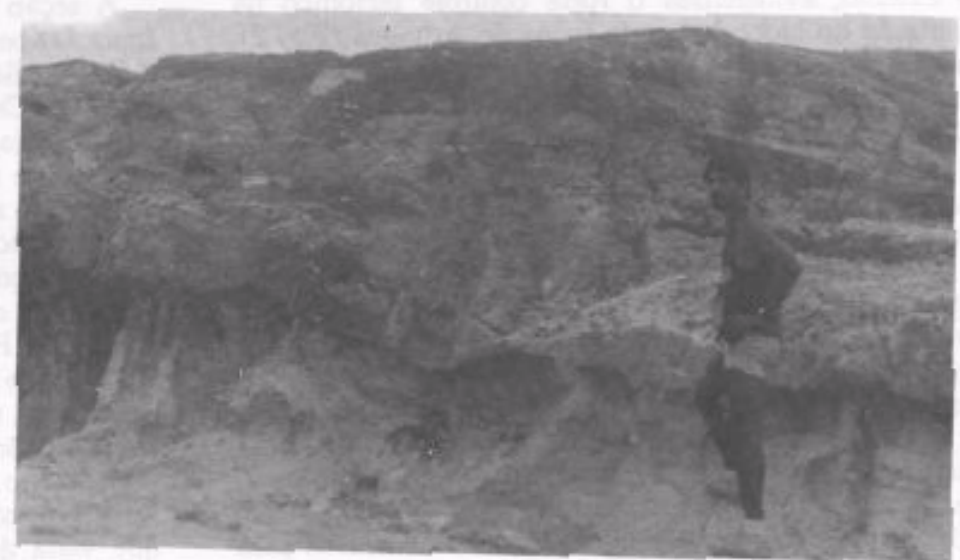

C

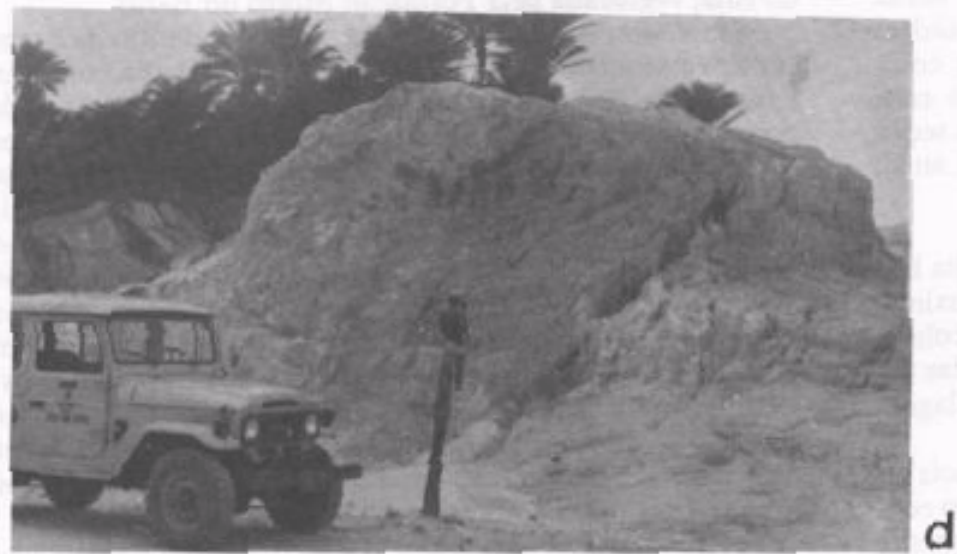

Figura 3 - A. Detalhe do traço do plano da falha da Fazenda Tijuco impregnado com óleo que sai dos níveis mais permeáveis. As zonas saturadas com óleo são preservadas da infiltração de argilas coloidais no processo de alteração do afloramento. B. Seixos de quartzo no conglomerado da Formação Sergi, cortados internamente pelo deslocamento da falha deAritaguá. C. Padrão en-echelon do plano da falha deAritaguá. D. Flower structure negativa em afloramento

Figure 3 - Outcrop aspects of Almada Basin. A. Oil seep in Fazenda Tijuca fault (Morro do Barro Formation); B. Quartz cobbles in Jurassic Sergi conglomerates cutted in the plane surface of Aritagua strike-slip fault;. C. En-echelon pattern of Aritagua fault; D. Negative flower-structure in Sergi Formation outcrop

valo, nesta área, está sendo interpretado como depositado numa plataforma na margem do rifte (fan-delta), plataforma esta associada com um abaixamento de nível do lago.
A evolução da fase rifte para a fase drifte nas bacias da margem continental brasileira tem seu registro nos sedimentos da Formação Taipus Mirim, de idade Alagoas (Albo-Aptiano), 


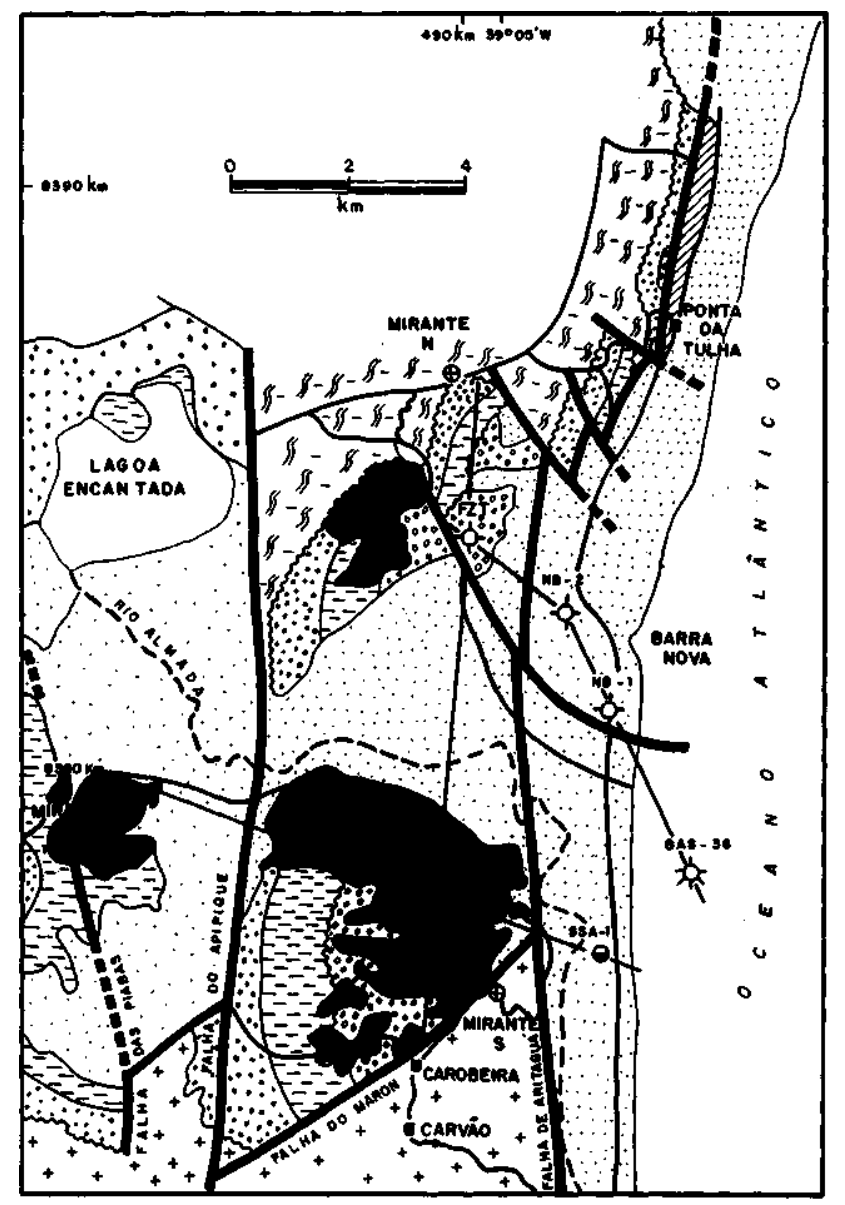

Figura 4 - Mapa geológico da Bacia do Almada. Simbologia como a da figura $2 \mathrm{C}$

Figure 4 - Geologic ma of Almada basin. Representation of formations in figure 2

que afloram $6 \mathrm{~km}$ a sul de Ilhéus, na foz do Rio Cururupe. Estes sedimentos transgridem em on lap a seção não marinha, localmente ultrapassando os limites da bacia mais antiga na direção do continente, e se assentando diretamente sobre o embasamento arqueano. Alitologia dominante é arenito, muito fino a grosso, seleção regular a má, carbonoso, argiloso, betuminoso; camadas com espessuras de 5 a $20 \mathrm{~cm}$, com estratificação cruzada de pequeno porte. $\mathrm{Na}$ foz do Rio $\mathrm{Cu}-$ rurupe, diques de diabásio (Apêndice 2), talvez de origem similar aos de Royal Charlotte e aos de Abrolhos, provocam metamorfismo de contato nos sedimentos Taipus-Mirim.

Com o evoluir da fase drifi, a circulação de águas marinhas se torna gradativamente mais ampla, o que fica registrado na presença dos calcários da plataforma do Albo-Cenomaniano. Estes calcários são reconhecidos como Formação Algodões (Fig. 5) e ocorrem no leito do Rio Almada, 1,5 km a montante de Aritaguá. Na sequência normal eles se sucedem à Formação Taipus-Mirim e estão presentes nos poços off-shore, compondo o Grupo Camamu. O Grupo Camamu não tem ocorrência contínua na borda da Bacia do Almada; ele é localmente removido, pêlos processos erosionais da transgressão do início do Neo-Cretáceo. A área transgredida registra sedimentação Campaniana da Formação Urucutuca, que assoreia o espaço criado na borda da bacia até restaurar uma fisiografia de plataforma. A sedimentação Urucutuca faz progradar o talude continental mar adentro, numa sedimentação continuada até os dias de hoje, quando a borda da plataforma está a uma distância de $20 \mathrm{~km}$ da linha de praia.
A Formação Urucutuca, que é reconhecida com este nome na margem continental brasileira da Bahia e do Espírito Santo, foi formalizada por Carvalho (1965), na parte emersa da Bacia de Almada. Ironicamente, os afloramentos na Vila de Urucutuca são essencialmente conglomeráticos, enquanto a formação é dominada por folhelhos de talude, com turbiditos localizados. Tais turbiditos são produtores de petróleo na Bacia do Espírito Santo, nos campos de Lagoa Parda e Fazenda Cedro. Bruhn \& Moraes (1989) apresentam uma comparação da geometria dos reservatórios produtores nestes campos com parâmetros medidos em superfície, nos conglomerados expostos na Bacia do Almada. No mesmo trabalho (Bruhn \& Moraes 1989, Fig. 2) fazem uma integração da ocorrência, em superfície, da Formação Urucutuca com a configuração delineada com sísmica de reflexão na plataforma continental adjacente, restaurando e isopacando o cânion de Almada, preenchido com sedimentos da Formação Urucutuca.

Coroando a sequência aflorante na Bacia do Almada, ocorre a Formação Rio Doce, representada por depósitos dominantemente arenosos, acumulados num complexo litorâneo do Eoceno até hoje; os sedimentos do complexo litorâneo Cenozóico cobrem metade da área emersa da bacia (Tab. 1 e Fig. 1). A faixa de restinga situada entre o curso do Rio Almada e a linha de praia (Fig. 4), por si só, constitui um enorme campo de trabalho para quem quiser se dedicar à geologia do recente.

Registra-se aqui também a presença localizada da Formação Barreiras, do Cenozóico, com resquícios preservados por sobre a sedimentação pré-rifte no centro-sul do compartimento interno. Os afloramentos ficam a sudeste de Castelo Novo, na área da estação de psicultura do Rio Almada (Ministério da Agricultura), e são constituídos por conglomerado organizado, com seixos perpendiculares à direção de corrente, base fortemente erosional; arenitos, larnitos e diarnictitos são subordinados e compõem a faciologia subaérea contemporânea à Formação Rio Doce. A Formação Barreiras apresenta-se como um complexo de leques aluviais depositados em condições de clima úmido.

ROTEIROS A Bacia do Almada, devido à sua área de ocorrência relativamente restrita, oferece perspectivas de roteiros para finalidades as mais diversas. Pode-se enfocar a visita de campo para:

A. Visão geral da bacia, com dois tipos de embasamento e a configuração do arcabouço tectônico, com compartimentos estruturais para finalidades exploratórias distintas e a coluna estratigráfica da bacia.

B. Aspectos estruturais de campo da falha de Aritaguá como elemento deforrnante da sequência pré-rifte e corno controlador da sequência do rifte transtensivo. C. Turbiditos canalizados da Formação Urucutuca, como modelo para compreensão da geometria externa de reservatórios petrolíferos.

D. Restinga do Rio Almada e os beach-rocks de Pontal, para análise de processos em ambientes recentes.

E. Relação entre rochas sedimentares, ígneas e metamórficas na Barra do Cururupe.

ACESSOS Ilhéus é servida por vôo diário, dista 360 km de Salvador por estrada asfaltada (BR-101), tem boa rede de hotéis e duas locadoras de automóveis.

De Ilhéus se vai por estrada asfaltada por $6 \mathrm{~km}$ para sul, para a Barra do Cururupe (Roteiro E). Em frente ao aeroporto, em Pontal, fica a exposição dos beach-rocks. Os afloramentos a sul de Ilhéus estão na maior parte na zona intermaré, portanto exige que se planeje a visita para o final da maré vazante.

Todos os outros roteiros são para o norte, e a referência de origem é o trevo do centro industrial, onde existe um posto Ipiranga. Saindo da praça da Catedral para o norte, na direção 


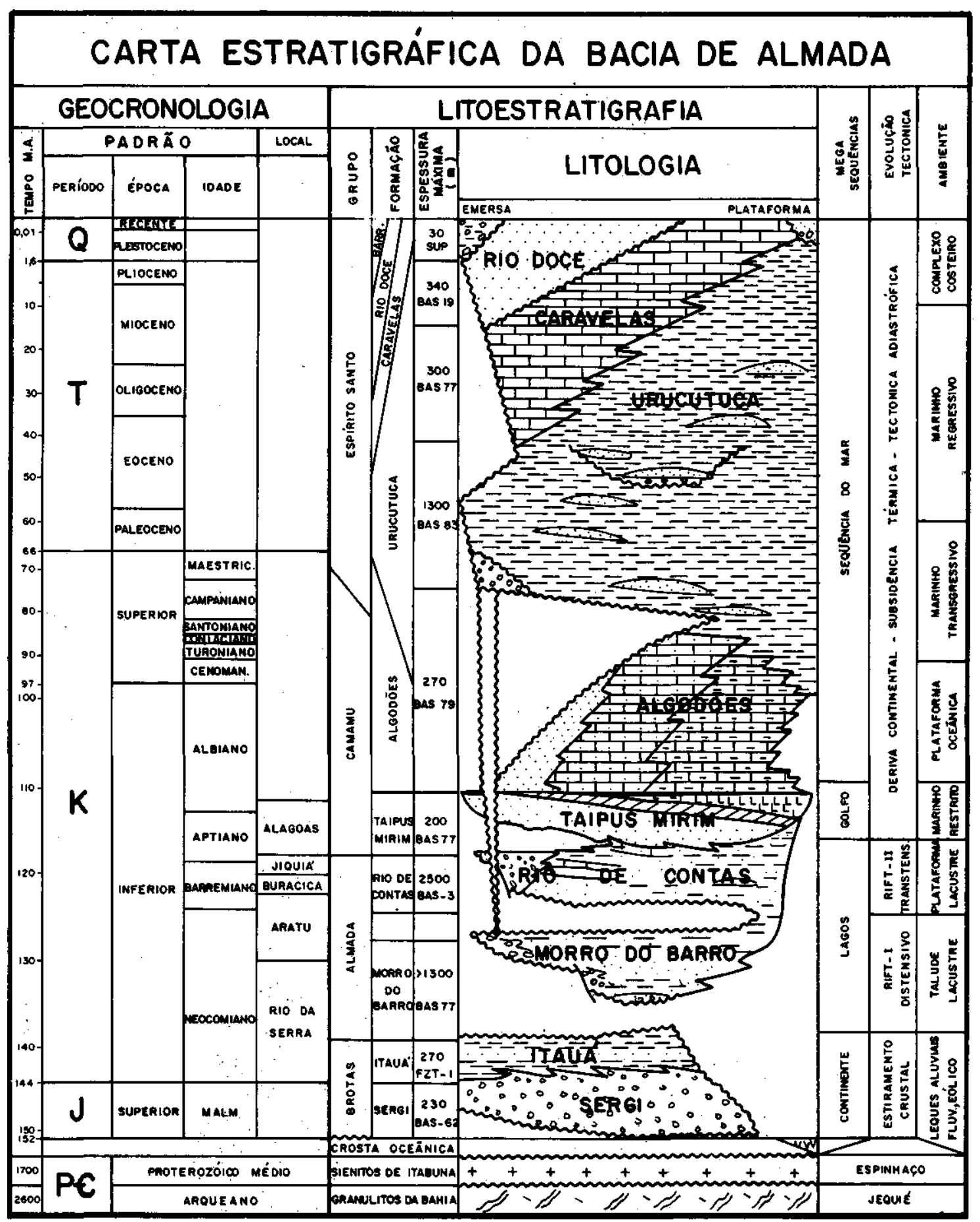

Figura 5 - Coluna estratigrafica da Bacia do Almada, adaptada e atualizada de Nascimento \& Araújo (1988). As linhas horizontais são linhas de tempo, referidas a uma escala geocronológica em milhões de anos, na primeira coluna. Devido às múltiplas discordâncias que a bacia experimentou principalmente no Cretáceo Inferior, chega-se à constatação curiosa de que, nesta época, o intervalo temporalmente mais curto, idade Barremiana, registra a maior espessura de sedimentos contínuos - a pouco conhecida Formação Rio de Contas (vide coluna de espessura má.:Ima). Na área de plataforma, a Formação Rio de Contas exibe uma taxa de preservação da ordem de 0,5m/1.000 anos, o que, por comparação com outros intervalos qusf oram intensamente retrabalhados, e por conseguinte exibem taxas bem maiores, atesta a complexidade da reconstituição da história geológica da bacia. A presença de crosta oceânica no talude continental é inferida por modelamento gravimétrico, conforme discutido no capítulo do Arcabouço Estrutural

Figure 5 - Stratigraphic column of Almada basin

de Uruçuca, o posto Ipiranga fica a $8 \mathrm{~km}$. A partir daí existem cinco estradas, todas sem pavimentação, mas transitáveis com automóvel comum ou microônibus. A figura 6 mostra um esquema viário para toda a bacia.
Apresenta-se a seguir um comentário suscinto dos afloramentos mais relevantes em cada um desses acessos e, ao final, um conjunto de tabelas com três roteiros recomendados para um dia de excursão em cada um. 
Acesso 1 Saída do posto Ipiranga. Torna-se uma estrada sem pavimento à direita, após o posto, na direção de Aritaguá e Sarnbaituba. No km 1,8, onde o Rio Almada faz uma suave inflexão para leste, há um afloramento do lado direito da estrada, de gnaisse de composição granulítica, com feldspatos e piroxênios, foliação bem marcada N10 (Apêndice 2). Este afloramento ilustra o embasamento metamórfico que é amostrado pêlos poços perfurados na bacia. Seguindo adiante $200 \mathrm{~m}$, no $\mathrm{km} \mathrm{2}$, se encontra de novo o gnaisse entre a estrada e o Rio Almada. Do lado esquerdo da estrada, no mesmo ponto, aflora o sienito, o embasamento ígneo dominante na borda sul da bacia. A estrada está sobre o contato, mas aqui a exposição não é boa.

Seguindo adiante por mais $3,5 \mathrm{~km}$, atinge-se a entrada para o acesso 2, no $\mathrm{km} \mathrm{5,5}$. Passe a entrada e siga na direção de Aritaguá, deixando no km 6,0 a antiga estação ferroviária de

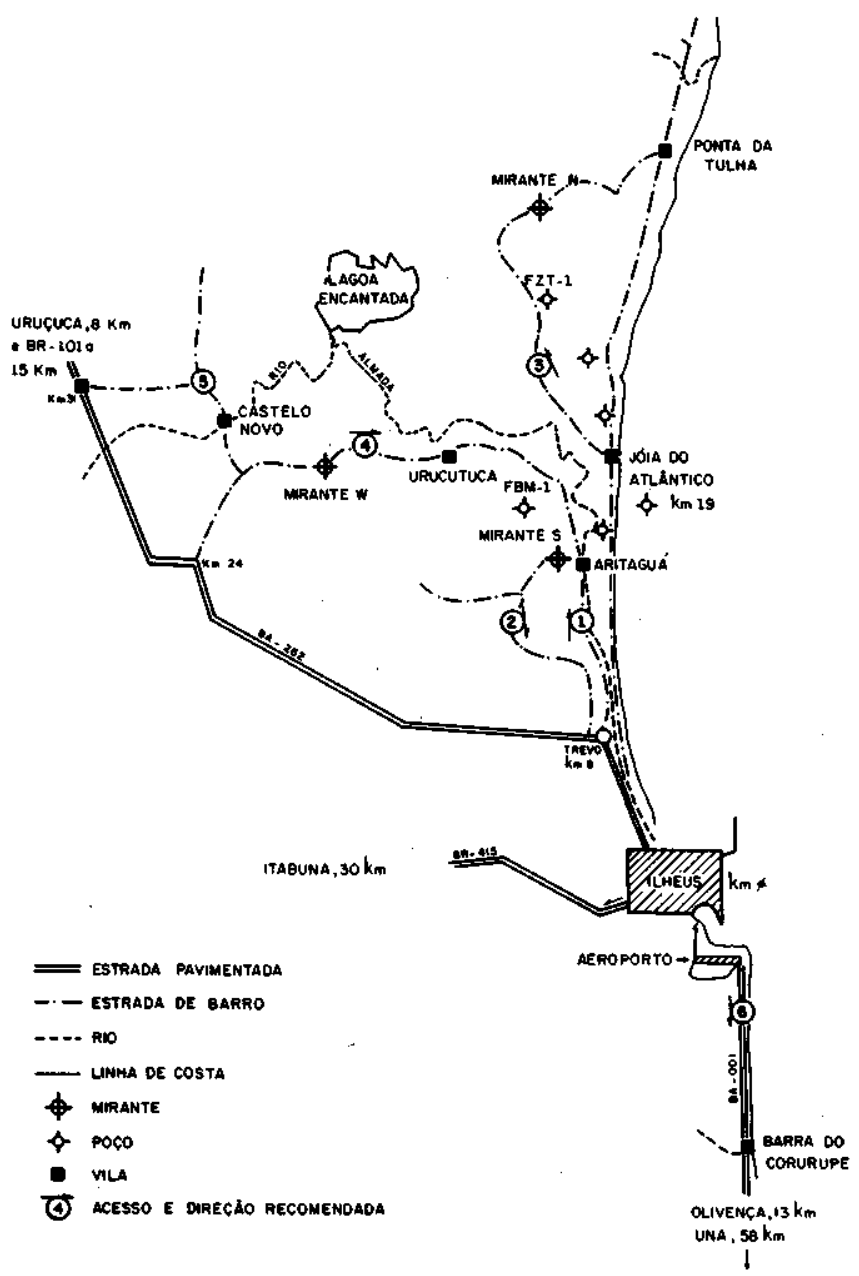

Figura 6 - Esquema viário da Bacia do Almada. Para distâncias e pontos de referências dos seis acessos aos afloramentos, vide texto. As distâncias marcadas no mapa são referidas ao centro de Ilhéus

Figure 6 - Route map for vishing Almada basin. Distances are ref ered to Illéus downtwn

Aritaguá à esquerda e, alcançando no km 6,8 uma exposição do contato gnaisse-sienito, no plano da falha que recebe o nome desta localidade, Falha de Aritaguá. $\mathrm{O}$ gnaisse aqui está intensamente fraturado, há uma fonte de água brotando no local e o plano da falha está orientado N10 (Apêndice 2). No km 7,9, há unia entrada para oeste, para a Fazenda do Noráu. Este ponto marca a interseção do traço da Falha do Maron, mais antiga, com o traço da Falha de Aritaguá, mais nova; o gnaisse aqui está cisalhado. O Rio Almada, neste ponto, perde seu caráter retilíneo e percorre urna série de meandros na mudança do curso de W-E para N-S (Fig. 4). Seguindo adiante, na direção de Sambaituba e Urucutuca, a estrada passa a correr sobre as rochas sedimentares cretáceas da Bacia do Almada.

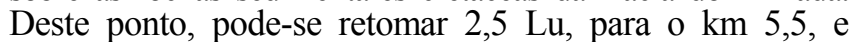
rumar para oeste, pelo final do Acesso 2.

Acesso 2 Esta estrada liga Aritaguá até a rodovia BA262,Ihéus-Uruçuca, passando pelas vilas de Carobeira e Carvão, e permitindo acesso à parte sul do compartimento central da Bacia do Almada. A entrada pela BA-262 é junto à indústria Joanes, que fica $0,5 \mathrm{~km}$ para oeste do posto Ipiranga (Fig. 6).

Subindo do km 5,5 do Acesso l, tomado aqui corno km O do Acesso 2, passa-se por uma jazida de material de construção, a qual é constituída por gnaisse cortado por diques de sienito (vide petrografia, no Apêndice 2), Os diques cortam quase perpendicularmente a lineação do gnaisse encaixante. A estrada contorna o morro onde está a jazida, subindo, e no topo, $\mathrm{km} \mathrm{1,9,} \mathrm{há} \mathrm{um} \mathrm{mirante} \mathrm{(deve-se} \mathrm{atravessar} \mathrm{a} \mathrm{cerca),} \mathrm{na}$ borda da bacia, no bloco alto da Falha do Maron (Fig. 4), aproximadamente na altura do paralelo de Aritaguá. Do mirante, se descortina a N20, a $7 \mathrm{~km}$ de distância, a arrebentação da Barra Nova (Fig. 4). A vista é ilustrada na foto 1 de Bruhn \& Moraes (1989, p. 241). A primeira crista, junto ao Rio Almada, é o conglomerado de turbiditos canalizados da Formação Urucutuca. A segunda crista, para norte, é a Formação Sergi, e a terceira crista o embasamento na borda norte da bacia. Deste ponto se descortina todo o compartimento externo, sendo as duas manchas vermelhas que se vêem ao longe (24 km ou 13 milhas náuticas) a ponta oriental da Serra Grande, onde a borda da bacia encontra a linha de praia.

Do km 1,9 (Mirante Sul), segue-se para sudoeste por 0,5 $\mathrm{km}(\mathrm{km} \mathrm{2,4)}$. Há uma bifurcação, com descida à direita, que cruza o traço da falha do Maron, cisalhando o sienito. O traço da falha tem atitude strike N20 e mergulho para NW. Esta descida só é possível a pé ou com tração em 4 rodas. Seguindo da bifurcação no $\mathrm{km} \mathrm{2,4}$ para sudoeste, na rodovia principal, alcança-se no km 3,7 uma entrada para oeste, para a Fazenda Boa Esperança. Tomando a entrada como referência, avista-se a sede da Fazenda 2,1 km adiante, numa ondulação onde afloram arenitos conglomeráticos com grânulos de embasamento e intraclastos de folhelho (Formação Urucutuca). A sede da fazenda fica a $2,6 \mathrm{~km}$ da entrada, sobre os folhelhos do Itauá, e a partir daí se tem uma exposição contínua numa extensão de $300 \mathrm{~m}$, onde se constata o caráter transicional do contato Sergi/Itauá numa subida à direita da sede da fazenda. Aqui convém ter urna bússola para medir as atitudes no Membro Tauá, no Itaparica e no Sergi.

O poço 1-FMB-1-BA, perfurado na área, após atravesar $307 \mathrm{~m}$ de sedimentos marinhos da Formação Urucutuca atinge por discordância a Formação Itauá. Passa o Membro Água Grande no intervalo 314-318 m, e a Formação Sergi no intervalo $381-483 \mathrm{~m}$, quando penetra no embasamento. $\mathrm{O}$ valor e a direção do mergulho medido nos afloramentos da Fazenda Boa Esperança coincide com os registros do dipmeter no FMB-1.

Retornando ao km 3,7 do Acesso 2, pode-se alcançar a BA-262 no centro industrial de Ilhéus seguindo para sudoeste $(6,4 \mathrm{~km})$, quando se passa pêlos lugarejos de Carobeira e Carvão; ou se pode voltar pelo Mirante Sul e Aritaguá, quando se percorre uma distância de $9,2 \mathrm{~km}$ numa estrada um pouco melhor. Em ambos os casos, o retorno é por sobre embasamento.

Acesso 3 O Acesso 3 percorre o compartimento externo da Bacia (bloco baixo da Falha de Aritaguá) e a parte norte do compartimento central. Saindo da praça da Catedral, na direção de Uruçuca, cruza-se o Rio Almada para as praias do norte, seguindo $11 \mathrm{~km}$ sobre a restinga, até o loteamento Jóia do Atlântico. Considera-se o km O na entrada do loteamento. 
Segue pelo lotearnento para WNW até o $\mathrm{km} \mathrm{4,8,} \mathrm{onde} \mathrm{uma}$ porteira na estrada separa a Fazenda Candeias da Fazenda Tijuca. Segue a direção da sede da Fazenda Tijuca, e no km 6,8 começa, da base para o topo, a melhor exposição da Formação Morro do Barro na bacia. O corte da estrada expõe o afloramento numa secão aproximadamente $30^{\circ}$ do strike. As camadas têm mergulho forte para NW, uma atitude discordante com a seção pré-rifte que mergulha ESE, conforme o dipmeter do poço 1-FZT-l-BA, perfurado a $400 \mathrm{~m}$ a NW do afloramento. A base do poço está conservada na posição de coordenadas latitude - $14^{\circ} 37^{\prime} 00^{\prime \prime} \mathrm{S}$ e longitude $39^{\circ}$ $05^{\prime} 30^{\prime \prime} \mathrm{W}$. O poço perfurou, da superficie até $70 \mathrm{~m}$, a Formação Morro do Barro; de 70 até $342 \mathrm{~m}$, na Formação Itauá que tem fauna de ostracodes da NRT 002.2 na parte superior e NRT002.1 (zoneamentode Vianaetal. 1971) na parte inferior. $\mathrm{O}$ arenito Água Grande está presente com $7 \mathrm{~m}$ de espessura e topo a $221 \mathrm{~m}$. A Formação Sergi foi encontrada a $342 \mathrm{~m}$, com boa permeabilidade e saturada com água de $3.000 \mathrm{ppm}$ de $\mathrm{NaCl}$. O topo do embasamento foi atravessado a $396 \mathrm{~m}$ de profundidade.

No início do afloramento (sudeste), uma falha transcorrente corta seixos no conglomerado, e o seu plano, com strike N 40, dip $=60^{\circ} \mathrm{SE}$, está impregnado com óleo (Fig. 3a). No bloco baixo, a seção exibe dobramentos de slumping. No bloco alto, que tem urna exposição contínua por mais de $50 \mathrm{~m}$, a seção empilhada tem espessura de $20 \mathrm{~m}$; razão aren/flh $>20$ e razão aren $/ \mathrm{cgl}=2$. Saindo do afloramento contínuo e subindo na seção, observam-se afloramentos descontínuos com razão aren/flh total, talvez, $=1$.

Um quilómetro após a locação do FZT-1 chega-se a um entroncamento. Para oeste (esquerda), vai-se para a Lagoa Encantada, cruzando a falha do Apipique e descendo do embasamento para a bacia (Fig. 4). Para nordeste, segue-se por mais um quilómetro circundado por cacau da Fazenda Tijuca,

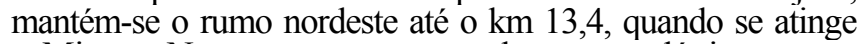
o Mirante Norte no contato, encoberto por elúvio, entre a Formação Sergi e o embasamento de gnaisse.

Do Mirante N se vê o Mirante S (embasamento), $11 \mathrm{~km}$ adiante, na direção NV176. Visa-se a Barra Nova a NV145. As ondulações altas mais próximas são os sedimentos da Formação Morro do Barro na Fazenda Tijuca. As ondulações, a média distância, após a planície de inundação do Rio Almada (que não tem o curso d'água visível daqui), são os conglomerados da Formação Urucutuca. A vista das cristas de Urucutuca, no sentido de criar um sentimento da geometria dos turbiditos canalizados, é aqui melhor do que a vista do Mirante S.

Do Mirante N se segue para ENE por $2 \mathrm{~km}$ por sobre o embasamento, até a Vila de Retiro, no $\mathrm{km} \mathrm{15,4.} \mathrm{Dai} \mathrm{se} \mathrm{deixa}$ a estrada Principal, descendo para a bacia na direção ESE, isto é, para a entrada da fazenda Ilha do Cedro. Um sistema de falhas transcorrentes dextrais e antitéticas desloca o embasamento para leste (Fig. 4), criando na topografia descontinuidade nas cristas de Sergi. Passa-se a entrada da Fazenda Ilha do Cedro no km 16,6, e no km 17,2 se alcança um grande afloramento da Formação Sergi. Deste afloramento do Sergi se visa a Barra Nova a NV173. Olhando para N55, delineia-se o Alto da Tulha - ultimo paredão de Sergi na parte norte da Bacia do Almada -, o qual fica bem exposto porque é deslocado dextralmente pela Falha de Ponta da Tulha (Carvalho et al. 1964); o plano da Falha de Ponta da Tulha passa entre o observador e o paredão, numa direção WNW-ESE, e no Alto da Tulha se vislumbra à distância em que o Sergi mergulha para SE.

Neste afloramento do km 17,2, a Formação Sergi é representada dominantemente por conglomerados e arenitos com estratificações cruzadas acanaladas de médio porte (até $5 \mathrm{~m}$ ), além de poucas camadas de lamito vermelho, descontínuas. Localmente, os seixos de quartzo do conglomerado, na parede do afloramento, são cortados em superfícies planas, indicando que o falhamento ocorreu com a rocha já consolidada (Fig. 3b); os cimentes principais são sílica e óxidos de ferro. No chão, no pavimento do afloramento, ocorrem zonas com largura de $2 \mathrm{~m}$, cisalhadas, e fraturas de direção entre N20 e N40. Uma direção de fratura secundária a NW é visível em corte, e propicia padrão en-enchelon para o conjunto (Fig. 3c). Os níveis amalgamados de conglomerado compõem camadas com espessuras de mais de $2 \mathrm{~m}$, um caráter diagnóstico do que Netto et al. (1982) usaram para diferenciar o então chamado Sergi Proximal. Nesse mapeamento (Netto et al 1982), as isópacas da Formação Sergi na Bacia do Almada truncam a borda da bacia com ângulo forte, indicando que a área de sedimentação se estendia para oeste, para além dos limites atuais.

$\mathrm{Na}$ parte mais alta do afloramento, para oeste, destaca-se urna estrutura em flor negativa, interpretada corno um ramo mais ocidental do sistema da Falha de Aritaguá. O bloco estruturado é cortado pela estrada quase perpendicularmente ao strike da falha. A exposição é boa. De cima do afloramento, descortina-se o traço da Falha de Aritaguá, até onde ela inflete mar adentro para delinear a borda norte do Alto de Olivença, em Ilhéus, onde o Grupo Brotas - aqui representado tao-somente pela Formação Sergi - afina-se e encontra o seu limite sul de ocorrência ao longo das bacias da costa brasileira.

Deste afloramento, no $\mathrm{km} \mathrm{17,2,} \mathrm{recomenda-se} \mathrm{descer} \mathrm{até} \mathrm{a}$ vila de Ponta da Tulha, no km 18,7 (vide Fig. 6 e Fig. 4), e daí seguir para norte por $2,6 \mathrm{~km}$ até a entrada da Fazenda Mamoan $(\mathrm{km} 21,3)$. Daí entra-se para oeste por $0,6 \mathrm{~km}$, para visitar o único afloramento da Formação Rio de Contas na bacia. O afloramento esta localizado no leito da estrada e na margem direta, muito alterado. A litologia exposta é limitada a arenito grosso, conglornerático, com restos de matéria orgânica. Continuando em frente, passa-se para o bloco alto da Falha de Aritaguá, com restos da Formação Sergi envolvidos por elúvio, e o gnaisse do embasamento. $\mathrm{O}$ retorno do $\mathrm{km} \mathrm{21,9}$ do Acesso 3 (foi considerado $\mathrm{km} \mathrm{O}$ na entrada do loteamento Jóia do Atlântico), até Ilhéus, é direto e cobre a distância de $30 \mathrm{~km}$.

Acesso 4 A entrada do Acesso 4 é no km 24 da BA262, $16 \mathrm{~km}$ após o trevo do Centro Industrial de Ilhéus (Fig. 6). Na entrada ( $\mathrm{km} 0)$, há uma placa indicando a Estação de Psicultura do Rio Almada. A estrada de terra é cortada por sobre o embasamento até o contato por discordância erosional, sem falha, pára a Formação Sergi. No km 1,6, já se constata a Formação Sergi no leito da estrada. No km 3,1, há uma bifurcação na Fazenda Almada. Para norte, há uma porteira trancada que leva à beira do Rio Almada, junto a Castelo Novo, um quilómetro a norte. Segue para leste, entrando no leito da antiga estrada de ferro de Ilhéus, serpenteante nos próximos $5 \mathrm{~km}$.

No km 3,8, alcança-se um grande afloramento da Formação Sergi, o qual é representativo de área maior, com bons afloramentos, que vem de Castelo Novo, até o Mirante de W (Fig. 5). A faixa de ocorrência do Sergi é bem exposta e mostra grande variação faciológica. Aqui, é possível realizar trabalhos didáticos sobre sistemas deposicionais em leques aluviais de clima árido, com retrabalhamento eólico. Dentro da Estação de Psicultura, no $\mathrm{km} \mathrm{4,1}$ do Acesso 4 e mais para leste num campo de futebol antes do Mirante W, ocorrem sedimentos avermelhados, com conglomerados organizados onde os seixos se orientam perpendicularmente à direção de corrente; contato basal discordante sobre a Formação Sergi. Estes sedimentos representam depósitos de leques aluviais, contêm larnitos avermelhados em camadas contínuas, arenitos acanalados com crostas de laterita e são distalrnente associados ao complexo litorâneo contemporâneo (Formação Rio Doce), permitindo inferir deposição em clima Úmido. Foram considerados como pertencentes à Formação Barreiras. Nesta área da bacia tem-se a oportunidade de analisar dois sistemas de leques aluviais depositados em condições climáticas distintas 
e, num trabalho de mais detalhe, estabelecer parâmetros para interpretação paleoclimática em sistemas de leques aluviais.

Seguindo para leste, alcança-se numa baixada $(\mathrm{km} 7,1)$ folhelho verde da parte superior da Formação Itauá, com bioturbação cilíndrica vertical. Sobe-se, então, o Morro de Urucutuca e no km 7,7 tem-se vista ampla, com a Lagoa Encantada cerca de $5 \mathrm{~km}$ a norte zero. Este ponto foi considerado como o Mirante W (Fig. 6 e Fig. 4). Daqui, vêem-se as cristas do Sergi bordejando o compartimento interno da Bacia do Almada, e mais ao longe, para $\mathrm{N}$ e W, uma crista mais alta, do embasamento metarnórfico.

A estrada contorna o Morro de Urucutuca e torna então rumo direto para leste, numa planície aluvial recente. A planície aluvial é construída por .vês rios que drenam de sul e de oeste, como tributários do Rio Almada. Eles arrasam o Urucutuca e constróem point-bars na faixa entre a Falha das Piabas e a Falha do Apipique (Fig. 4), interagindo com a planície de inundação do Rio Almada, que se estreita no meridiano de Urucutuca (Fig. 4) e se abre em seguida para o compartimento central, numa transição para o complexo litorâneo retrocedente.

No km 12 do Acesso 4, chega-se à Vila de Urucutuca, onde começa uma sequência de seis afloramentos num trecho de $5,5 \mathrm{~km}$ descritos em detalhe por Bruhn \& Moraes (1989). A descrição é enriquecida por grande número de fotos, seções colunares, levantamentos quantitativos e mapas. Estes afloramentos apresentam os turbiditos canalizados da Formação Urucutuca, de Carvalho (1965), os quais preenchem o talvegue proximal do Cânion de Almada (Bruhn \& Moraes, 1989, Fig. 2, p. 237). Na vila de Urucutuba, km 12, está a seção tipo da Formação Urucutuca, representada por espessa seção de conglomerados intraformacionais, com seixos de rocha argilosa. No km 14,4, na antiga estação ferroviária de Sambaituba, o plano da exposição é quase perpendicular à direção de paleocorrente: apresentam-se cinco canais amalgamados, com conglomerado intraformacional no talvegue e arenitos estratificados no topo e nas margens. O corte de estrada, 1,2 $\mathrm{km}$ adiante $(\mathrm{km} \mathrm{15,6)}$, secciona a sequência paralelamente à direção de paleocorrente. Neste ponto, a base do afloramento registra um escorregamento por slumping, recoberto por diarnictitos (pebbly-mudstone), seguido por folhelhos intrudidos por diques de arenito e recobertos por um canal preenchido por arenitos. Na base do último afloramento desta série, no $\mathrm{km} 17,5$, os diques marginais do talude pretérito, com folhelhos bioturbados preservados numa seção com $10 \mathrm{~m}$ de espessura, são cortados por turbiditos canalizados do upper-fan, constituídos por uma seção de $9 \mathrm{~m}$ de conglomerados e arenitos com sequências de Bouma. Seguindo pela estrada na direção de Aritaguá, alcança-se o embasamento no km 18,2, o ponto final $(\mathrm{km} 7,9)$ do Acesso 1 .

Acesso 5 O Acesso 5 cobre a borda oeste do compartimento interno, onde se visita o embasamento de gnaisse numa cachoeira, no norte da bacia, o Sergi, em Castelo Novo, e o Itauá, com um belo afloramento do arenito Água Grande na Fazenda Vencedora. A cobertura discordante da Formação do Barro foi encontrada somente em afloramentos mal preservados em roças de cacau, nos quais se constatam conglomerados granulosos e arenitos com espessura decirrétrica, médios e mal selecionados. Toda a seção é afetada pelo fraturarnento que delimita a borda oeste da Bacia do Almada.

A entrada do Acesso 5 (Fig. 6) está localizada no km 31 da rodovia Ilhéus - Uruçuca (km O do Acesso 5). Aí, deixa-se a estrada asfaltada e segue-se para leste, na direção de Castelo Novo.

No km 0,5 aflora o Membro Sergi no leito da estrada, muito fraturado; o contato com o embasamento é coberto, mas a diferença de nível entre o embasamento e o Membro Sergi não chega a $5 \mathrm{~m}$. No km 1,3, as fraturas no Membro Sergi são N-S, com mergulho forte para E, preenchidas por óxidos de ferro. No km 1,6, há um afloramento do Itauá, com folhelho dominante e camadas de arenito intercaladas. $O$ arenito é fino a médio, apresentando seleção regular e camadas com espessura de $1 \mathrm{~m}$ exibindo estratificação cruzada tabular. No km 4,2, há um entroncamento, com urna variante para sul e outra para norte.

A variante de sul vai para Castelo Novo, $2 \mathrm{~km}$ para sul, a vila na qual Kilson Carvalho implantou o acampamento da TG-10, equipe da Petrobrás que realizou o mapeamento sistemático da bacia no período de novembro de 1961 até outubro de 1962 (1:25.000). Esta equipe de superfície contava com dois jeeps, uma caminhoneta, três barcos, uma sonda pequena para furos rasos e forte apoio do laboratório de paleontologia. Uma turma de braçais limpava os afloramentos para análise de três geólogos, aliás um procedimento recomendável, porque a vegetação exuberante na região mascara em muito as relações estratigráfícas nos afloramentos. Castelo Novo fica na margem do Rio Almada, no contato entre um grande afloramento na Formação Sergi e o embasamento cristalino.

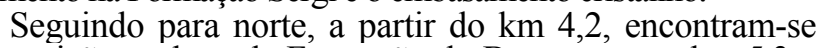
exposições pobres da Formação do Barro, entre o km 5,3 e 5,5. São níveis de $20 \mathrm{~cm}$ de conglomerado granuloso, seixoso, organizado; arenitos com camadas de menos de um metro de espessura, granulação média, mal selecionado. Fraturas, como no Sergi, orientadas N-S são menos abundantes, como se o material fosse menos rúptil. Há manchas de óleo no arenito. No km 7,2, Fazenda Vencedora, ocorre folhelho cinza, bandeado de marrom, com boa fissilidade, fraturado; arenito fino a grosso, com camadas de $2 \mathrm{~m}$ de espessura, base e topo quase planos, estratificação cruzada de pequeno ângulo; e lamito creme, calcífero. No km 8, Fazenda Lagoa Pequena, há uma cachoeira que cruza o traço da falha da Serra Pilheira (Fig. 1); o riacho desce do embasamento de gnaisse para escoar sobre uma estreita faixa de ocorrência da Formação Itauá e formar à jusante uma zona pantanosa que se espalha para sudeste até integrar a bacia de inundação do Rio Almada.

Acesso 6 O Acesso 6 sai do aeroporto de Ilhéus, em Pontal, e segue em estrada asfaltada $6 \mathrm{~km}$ para o sul, até a Barra do Cururupe. Os afloramentos estão na praia, a norte da barra, e têm extensão de cerca de $700 \mathrm{~m}$. Só são observáveis com a maré vazia; procure visitá-los de um dia antes até 5 dias depois da lua cheia ou lua nova, porque nestes períodos o instante da baixa-mar fica entre 9 e 13 horas, e a maré é grande, aumentando a área de exposição. Você pode contar com pelo menos quatro horas de boa exposição, duas antes e duas depois do instante da baixa-mar.

O afloramento fica na borda norte do Alto de Olivença, é uma feição estrutural que separa a Bacia do Almada da Bacia do Jequitinhonha. Existem grandes contrastes entre as duas bacias, destacando-se em Jequitinhonha a presença de rochas vulcânicas cretáceas, e a ausência do registro do Andar Dom João (Grupo Brotas, Formação Aliança e Formação Sergi). A nomenclatura estratigráfica da Bacia do Jequitinhonha está mais afim com a do Espírito Santo do que com Camamu-Almada.

$\mathrm{Na}$ parte norte dos afloramentos, na Barra do Cururupe, cerca de $800 \mathrm{~m}$ a norte da foz do rio, ocorre um domo elipsoidal, com cerca de $25 \mathrm{~m}$ no eixo maior e $12 \mathrm{~m}$ no eixo menor, onde as camadas de arenito da Formação Taipus-Mirim mergulham radialnente. Os arenitos, ocorrem em camadas com 2 a $20 \mathrm{~cm}$ de espessura, sem estratificação visível, exceto ondulas. Eles são cinza escuro a preto, muito finos, seleção regular a má, carbonosos, argilosos, duros, calcíferos e cimentados. Nos níveis de acarnarnento ocorrem concreções calcíticas, impregnações de betume e, por vezes, veios de calcita fibrosa. Depósitos recentes similares ocorrem em áreas protegidas na Baia de Camarnu, em ambientes de baixa energia, cortados por canais de maré. Estes ambientes são referidos pêlos habitantes locais como zona de apicurn. Estão associados a restingas com 
turfeiras e lagunas. No caso da Formação Taipus-Mirim, nas áreas marginais da Bacia de Camamu, ocorrem depósitos evaporíticos, com anidrita e gipsita (Netto 1977, para detalhes).

Para sul, outros domos maiores ou menores que o inicial ocorrem, sempre dobrando rochas da Formação Taipus-Mirim. $\mathrm{O}$ arenito cinza escuro muito fino continua sendo a litologia dominante, mas ocorrem também níveis de menos de $10 \mathrm{~cm}$ de arenito grosso, com quartzo subarredondado a subangular, além de folhelhos pretos, sílticos, micáceos, muito calcífero, com nódulos centimétricos de arenito fino, em camadas de 60 a $70 \mathrm{~cm}$ de espessura.

$\mathrm{Na}$ altura da metade da zona de afloramento, os arenitos vão ficando mais cimentados. $\mathrm{O}$ cimento passa gradualmente a compor mais de $50 \%$ da rocha, que parte em planos definidos ricos em sulfetos. A rocha vai-se enriquecendo em minerais escuros e se tornando um diabásio. A textura da rocha ígnea é diferenciada - em poucos metros de afloramento passa de afanítica até fanerítica; localmente, é vesicular.

Para sul, o diabásio (Apêndice 2) sobe pelas bordas do gnaisse que compõe o morro junto à estrada. $\mathrm{O}$ gnaisse é acastanhado, feldspático, com cristalinidade grosseira e localmente bandeado. As fraturas no gnaisse estão na direção do eixo das dobras no sedimento. No contato gnaisse/diabásio, há pedaços de gnaisse englobados ou absorvidos pela intrusão. No final da praia, junto à Foz do Cumrupe, o gnaisse mergulha para oeste. Neste local ocorrem, na borda e no leito do Rio Cururupe, conglomerados e beach-rocks recentes.

\section{REFERÊNCIAS BIBLIOGRÁFICAS}

BRUHN, C.H.L. \& MORAES, M.A.S. 1989. Turbiditps da Formação Urucutuca na Bacia de Almada, Bahia: um laboratório de campo para estudo de reservatórios canalizados. Bol. Geoc. PETROBRÂS, 3(3):235-267.

CARVALHO, K.W.B. 1965. Geologia da Bacia Sedimentar do Rio Almada. Boi Téc. PETROBRÁS, 8(1):5-55.

CARVALHO, K.W.B.; PEIXOTO, L.; GARRIDO, J.L. 1964. Mapa Geológico Escala 1:25.000. Salvador, PETROBRÂS/RPBA/SETEX. (Rei. Int. 738).

FUSCHILO, B., \& ARAR1PE, P.T. 1966. Relatório de Acompanhamento do poco 2-NBst-1-BA (prospecto de Nova Brasília, Bacia de Almada, Bahia). Salvador PETROBRAS/DEXBA. (Rei. Int. 1867).

INDA, H.A.V. \& BARBOSA, J.F. 1978. Mapa Geológico do Estado da Bahia, ao milionésimo. Salvador, Secretaria das Minas e Energia, CPM. 13 p. (Texto Explicativo).

NASCIMENTO, M.M. \& ARAÚJO, M.B. 1988. Carta Estratigráfica das Bacias de Camamu-Altnada. Rio de Janeiro, PETROBRAS/DEPEX. (Inédita).
NETTO, A.S.T. 1977. Barita de Camamu: considerações sobre a génese. Boi. Téc. PETROBRÁS, 20(2):77-92.

NETTO, A.S.T. 1978. A implantação da fase-rift na Bacia do Recôncavo. In: CONGR.BRAS.GEOL., 30. Recife, 1978. Anais... Recife, SBG. v. 1, p.506-517.

NETTO A.S T ; BARROSO A.S · BRUNH, C.H.L ; CAIXETA J.M. MORAES, M.A.S. 1982. Projeto Andar Dom João. Salvador, PETROBRÁS/DEXBA. 193. . (Rei. Int. 1726).

VIANA, C.F.; GAMA, E., Jr.; SIMOOES, I.A.; MOURA, J.A.; FONSECA, J.R.: ÄLVES, R.J. 1971. Revisão Estratigráfica da Bacia do Recôncavo/Tucano. Boi. Téc. PETROBRAS, 14(3/4): 157-192.

MANUSCRITO RG001

Recebido em 5 de outubro de 1990

Revisão do autor em 27 de dezembro de 1990 Revisão aceita em 27 de dezembro de 1990

Apêndice 1 - Tabelas com roteiros recomendados para visita à bacia em três dias

Recomenda-se que, além deste roteiro, o visitante tenha à mão os trabalhos de Carvalho (1965) e Bruhn \& Moraes (1989). São desejáveis as fotos aéreas da Cruzeiro do Sul. Existem três coberturas: 1:25.000, 1:60.000 e 1:108.000; qualquer delas é suficiente. Para quem dispuser de tempo, uma visita aos escritórios da CEPLAC, na estrada Ilhéus-Itabuna, vai permitir analisar as fotos, com esteroscópio de espelho, disponível para o usuário. As fotos não saem de lá. O horário da CEPLAC é das 8 às 14 horas.

Bússola, binóculo e martelo vão permitir melhor aproveitamento da visita. A medida de atitudes vai ajudar a separar as sequências discordantes quando os contatos são cobertos, e a observação dos mirantes fica enriquecida com um binóculo. Na área a norte de Ilhéus, não há local para lanche, e o visitante deve levar algo para se alimentar durante o dia. Um casaco de nylon pode ser confortável para urna chuva eventual. É possível percorrer os roteiros recomendados de bermuda, mas em alguns locais vai ser tentador entrar numa mata rala que talvez arranhe as pernas. A visita à Barra do Cururupe pode ser feita com roupa de praia. Almoço típico pode ser arranjado.

Quanto mais cedo for a saída, mais proveitoso fica o dia. Programar a saída do hotel entre 7 e 8 horas da manhã é suficiente. No dia mais longo, vai ser coberto um percurso de $54 \mathrm{~km}$ e realizadas nove paradas. O dia mais curto é o da visita à Barra do Cururupe. 
$\mathbf{1}^{\text {a }}$ dia - Tipos de embasamento, sedimentação pré-rifte no compartimento central e turbiditos canalizados da fase drift. Acessos 1,2 e 4

km AFLORAMENTO/PONTO DE REFERENCIA

0,0 Hotel Ilhéus Praia-Praça Dom Eduardo

8,0 Posto Ipiranga, no trevo do Centro Industrial de Iliéus

9,0 PARADA N 1 - Embasamento ígneo

14,0 Carobeira

17,0 PARADA NN 2 - Fazenda Boa Esperança

23,0 PARADA № 3 - Mirante Sul

26,0 PARADA № 4 - Aritaguá

27,0 Fazenda do Norau

33,0 PARADA № 5 - Urucutuca

35,4 PARADA NN 6 - Sambaituba

\section{6,6 PARADA № 7}

\section{8,5 PARADA N ${ }^{2} 8$}

\section{3,5 PARADA NN 9}

45,5 Posto Ipiranga

54,0 Hotel Ihéus Praia
PRINCIPAIS ASPECTOS DE INTERESSE/INSTRUÇŌES

Seguir pela Av. Soares Lopes, no sentido norte, e pegar estrada para Uruçuca.

Seguir até a Industria Joanes e dobrar à direita na direção de Carvão e Carobeira.

Sienitos de Itabuna.

Seguir por mais $300 \mathrm{~m}$ e virar à esquerda, para Bom Gosto.

Vide descrição no Acesso 2, inclusive do poço 1-FMB-1.

Medir atitudes do Itauá e Sergi, em contato gradacional.

Retorno.

Vide descrição no Acesso 2.

Faltha de Aritaguá. Veja aqui o gnaisse arqueano intensamente fraturado. Descriçăo no Acesso 1.

Borda da Bacia Cretácea.

Seção tipo da Fm. Urucutuca.

Vide Acesso 4.

Afloramento 1 de Bruhn \& Moraes (1989).

Afloramento 2 de Bruhn \& Moraes (1989).

Turbiditos em seção strike.

Vide Acesso 4.

Turbiditos em seção dip.

Afloramento 3 de Bruhn \& Moraes (1989).

Vide Acesso 4.

Fazenda Monte Belo

Afloramento 6 de Bruhn \& Moraes

Vide Acesso 4.

Escarpa do plano da Falha de Aritaguá.

Recomenda-se jantar pitu no "O céu é o limite", próximo à estação rodoviária.

$2^{2}$ dia - Aspectos estratigráficos e sedimentológicos da Seqüência Rifte. A Falha de Aritaguá. Acesso 3.

km AFLORAMEN'TO/PONTO DE REFERENCIA

0,0 Hotel Ihéus Praia - Praça Dom Eduardo

6,0 Ponte sobre o Rio Almada. Acesso às Praias do Norte

17,0 Loteamento Jóia do Atlântico

24,0 PARADA № 1 - Fazenda Tijuca

25,0 Entroncamento

30,4 PARADA № 2 - Mirante Norte

32,4 Vila de Retiro

34,2 PARADA № 3 - Formação Sergi/Falha de Aritaguá

35,7 Ponta da Tulha

38,3 Entrada da Fazenda Mamoan

38,9 PARADA № 4

69,0 Hotel Ihéus Praia

$3^{2}$ dia - Relação entre rochas sedimentares, igneas e metamórficas na Barra do Cururupe. Acesso 6.

km AFLORAMENTO/PONTO DE REFERENCIA

0,0 PARADA № 1 - Aeroporto

6,0 PARADA N² 2 - Barra do Cururupe
PRINCIPAIS ASPECTOS DE INTERSSE/INSTRUÇŌES

Seguir pela Av. Soares Lopes, no sentido norte, e pegar a estrada para Uruçuca.

Atravessar a ponte e seguir para norte, paralelo à praia.

Entrar para oeste, passando pelo clube do loteamento e seguindo para a Fazenda Tijuca.

Fm. Morro do Barro. Vide descrição no km 6,8 do Acesso 3, e foto na figura $3 a$.

Dobrar à direita, para nordeste.

Ponto alto no embasamento. Vide descrição no $\mathrm{km} 13,4$ do Acesso 3.

Desce para bacia numa variante à direita, ESE, para a Fazenda Illa do Cedro.

Grande afloramento onde se faz análise estrutural e sedimentológica.

Segue para esquerda, para norte.

Vira à esquerda, para oeste.

Vide descrição no $\mathrm{km} \mathrm{21,9}$ do Acesso 3. Retoma daqui.

Os afloramentos deste dia são observáveis apenas com maré baixa. Se a baixa mar for pela manhã, pode-se retornar no mesmo dia, via aérea ou terrestre. Se a baixa mar for pela tarde, pode-se visitar cedo, pela manhã, a CEPLAC, na estrada que liga Ilhéus a Itabuna; neste caso, pode-se também analisar os sienitos de Itabuna nos cortes de estrada e no leito do Rio Cachoeira, na margem do qual passa a estrada, e depois seguir para a Barra do Cururupe.

\section{PRINCIPAIS ASPECTOS DE INTESSE/INSTRUÇÕES}

Beach-rock na praia em frente à pista do aeroporto. Afloramento de grande extensão e diversidade. Vide descrição 
Apêndice 2 - Petrografia microscópica do embasamento e intrusivas aflorantes

\begin{tabular}{|c|c|c|c|c|}
\hline ÁREA & ROCHA/LOCAL & TEXTURA & COMPOSIÇĀO MC & DAL \\
\hline \multirow{6}{*}{ 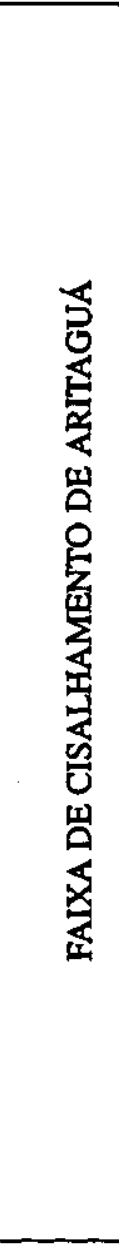 } & $\begin{array}{l}\text { GNAISSE } \\
\text { * fonte na Vila de Aritaguá }\end{array}$ & $\begin{array}{l}\text { foliação gnáissica } \\
\text { estiramento de cristais } \\
\text { contatos interpenetrados }\end{array}$ & $\begin{array}{l}\text { quartzo } \\
\text { feldspatos potássicos } \\
\text { plagioclásios } \\
\text { piroxênios } \\
\text { biotita } \\
\text { opacos }\end{array}$ & $\begin{array}{r}36 \% \\
27 \% \\
21 \% \\
7 \% \\
6 \% \\
3 \%\end{array}$ \\
\hline & $\begin{array}{l}\text { GNAISSE } \\
\text { * pedreira na subida para } \\
\text { Mirante Sul }\end{array}$ & $\begin{array}{l}\text { foliação gnáissica } \\
\text { estiramento de cristais } \\
\text { contatos interpenetrados e amebóides } \\
\text { extinçăo ondulante }\end{array}$ & $\begin{array}{l}\text { quartzo } \\
\text { microclínio } \\
\text { ortoclásio } \\
\text { plagiclásios } \\
\text { feldspatos potássicos } \\
\end{array}$ & $\begin{array}{r}49 \% \\
31 \% \\
15 \% \\
5 \% \\
34 \% \\
\end{array}$ \\
\hline & $\begin{array}{l}\text { GRANULITO } \\
\text { (chamockítico) } \\
\text { * escarpa da falha }\end{array}$ & $\begin{array}{l}\text { granoblástica inequigranular } \\
\text { relação de contatos poligonais e amebóides } \\
\text { ripas de biotita com orientação incipiente } \\
\text { quartzo policristalino com extinção ondulante }\end{array}$ & $\begin{array}{l}\text { Plagioclásios } \\
\text { piroxênios } \\
\text { quartzo } \\
\text { biotita } \\
\text { opacos }\end{array}$ & $\begin{array}{r}30 \% \\
15 \% \\
15 \% \\
4 \% \\
2 \%\end{array}$ \\
\hline & $\begin{array}{l}\text { SLENITO } \\
\text { ("hiperstênio" sienito) } \\
\text { * intrusiva no gnaisse }\end{array}$ & $\begin{array}{l}\text { granular fina } \\
\text { cristais de piroxênio com orientação incipiente }\end{array}$ & $\begin{array}{l}\text { "hiperstênio" } \\
\text { plagioclásios } \\
\text { felspatos potássicos } \\
\text { microclínio } \\
\text { magnetita }\end{array}$ & $\begin{array}{r}49 \% \\
26 \% \\
21 \% \\
3 \% \\
1 \% \\
\end{array}$ \\
\hline & $\begin{array}{l}\text { SIENITO } \\
\text { (anfibólio sienito) } \\
\text { * intrusiva em gnaisse } \\
\text { da pedreira }\end{array}$ & $\begin{array}{l}\text { equigranular } \\
\text { cristais alongados com orientação incipiente } \\
\text { piroxênios alterados para anfibólios }\end{array}$ & $\begin{array}{l}\text { anfibólios } \\
\text { feldspatos potássicos } \\
\text { piroxênios } \\
\text { plagioclásios } \\
\text { opacos } \\
\text { biotita }\end{array}$ & $\begin{array}{l}35 \% \\
24 \% \\
22 \% \\
11 \% \\
5 \% \\
3 \%\end{array}$ \\
\hline & $\begin{array}{l}\text { DIABÁSIO } \\
\text { * escarpa da falha }\end{array}$ & $\begin{array}{l}\text { textura sub-ofitica } \\
\text { filonitizaçăo observada em microfraturas com } \\
\text { orientação preferencial }\end{array}$ & $\begin{array}{l}\text { egirina-augita } \\
\text { plagioclásios } \\
\text { feldspatos potássicos } \\
\text { magnetita }\end{array}$ & $\begin{array}{r}44 \% \\
35 \% \\
13 \% \\
8 \%\end{array}$ \\
\hline 舒 & $\begin{array}{l}\text { SIENITO } \\
\text { (alcali-feldspático) } \\
\text { * Estrada Ilhéus Unuçuca }\end{array}$ & $\begin{array}{l}\text { inequigranular } \\
\text { contatos poligonais e amebóides } \\
\text { talhe grosseiro }\end{array}$ & $\begin{array}{l}\text { feldspatos potássicos } \\
\text { anfibólios } \\
\text { piroxênios } \\
\text { magnetita }\end{array}$ & $\begin{array}{r}90 \% \\
5 \% \\
3 \% \\
2 \%\end{array}$ \\
\hline 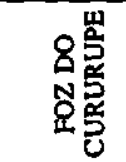 & DIABÁSIO & $\begin{array}{l}\text { textura ofitica } \\
\text { piroxênios muito alterados } \\
\text { algumas amostras de diabásio encontram-se muito } \\
\text { alteradas, exibindo textura esferulítica }\end{array}$ & $\begin{array}{l}\text { plagioclásios } \\
\text { feldspatos potássicos } \\
\text { piroxênios } \\
\text { magnetita }\end{array}$ & $\begin{array}{l}45 \% \\
12 \% \\
18 \% \\
25 \%\end{array}$ \\
\hline
\end{tabular}

